\title{
PENGARUH ASOSIASI MEREK, KESETIAAN MEREK, KESADARAN MEREK DAN CITRA MEREK TERHADAP EKUITAS MEREK PADA PENGGUNA SMARTPHONE OPPO
}

\author{
Yenny Lego \\ Universitas Tarumanagara \\ yennyl@fe.untar.ac.id \\ Oey Hannes Widjaya \\ Universitas Tarumanagara \\ hannesw@fe.untar.ac.id
}

\begin{abstract}
The very high growth of smartphone users in Indonesia makes companies that issue smartphone products have to try to be the best among other smartphone companies. Currently, OPPO is in second place in the smartphone market share in Indonesia in the second quarter of 2019. The aim of this study is to determine brand association, brand loyalty, brand awareness and brand image have an influence on brand equity. The sampling technique was carried out by purposive sampling. The questionnaire was distributed to 150 respondents in Karawaci Tangerang who were OPPO smartphone users. The results of this study indicate that there is an effect of brand association on brand equity, meanwhile, brand loyalty, brand awareness, and brand image have no influence on brand equity.
\end{abstract}

Keywords: Brand Associations, Brand Loyalty, Brand Awareness, Brand Image, Brand Equity

\footnotetext{
ABSTRAK

Pertumbuhan pengguna smartphone di Indonesia yang sangat tinggi membuat perusahaan menjadi isu produk smartphone harus berusaha menjadi yang terbaik di antara perusahaan smartphone di Indonesia pada kuartal kedua tahun 2019. Tujuan dari penelitian ini adalah untuk mengetahui asosiasi merek, loyalitas merek, kesadaran merek dan citra merek berpengaruh terhadap ekuitas merek. Teknik pengambilan sampel dilakukan dengan purposive sampling. Kuesioner dibagikan kepada 150 responden di Karawaci Tangerang yang merupakan pengguna smartphone OPPO. Hasil penelitian ini menunjukkkan bahwa ada pengaruh asosiasi merek terhadap ekuitas merek, sedangkan loyalitas merek, kesadaran merek, dan citra merek tidak berpengaruh terhadap ekuitas merek.

Kata Kunci: Asosiasi Merek, Loyalitas Merek, Kesadaran Merek, Citra Merek, Ekuitas Merek
} 


\section{PENDAHULUAN}

Perkembangan teknologi informasi beberapa tahun belakangan ini bertumbuh dengan cepat. Teknologi informasi saat ini dapat memberikan kemudahan bagi masyarakat dalam melakukan pekerjaan sehari-hari. Perkembangan teknologi juga membuat perilaku masyarakat berubah dalam mengakses informasi, komunikasi, dan bertransaksi. Masyarakat di Indonesia juga sudah mulai merespon perkembangan teknologiyang sudah berkembang saat ini. Hal ini dapat dilihat dari masyarakat yang sudah mulai terbiasa dalam menggunakan smartphone nya dalam kehidupan sehariharinya misalnya dalam bekerja, berkomunikasi, dan mendapatkan informasi. Kondisi ini dipengaruhi oleh teknologi internet dan perkembangan ponsel pintar. Mengutip dari data lembaga riset IDC yang dimuat di CNBC Indonesia, disebutkan pada kuartal II-2019 Samsung masih menguasai pangsa pasar ponsel terbesar di Indonesia yang diikuti dengan OPPO, Vivo, Xiaomi, dan merek ponsel lainnya. Sesuai dengan persentasenya Samsung menguasai $26,9 \%$ pasar ponsel Indonesia. Sisanya OPPO 21,5\%, Vivo 17\%, Xiaomi 16,8\%, Realme $6,1 \%$. Sebanyak $11,7 \%$ nya diisi oleh merek ponsel lainnya. Pada saat ini OPPO berada di posisi kedua dalam pangsa pasar smartphone di Indonesia pada kuartal II2019. OPPO Electronic Corp, Ltd berdiri pada tahun 2004 sebagai produsen elektronik yang berlokasi di Dongguan, Guangdong, Negara China. Sebelum merambah ke teknologi mobile smartphone, OPPO memproduksi peralatan elektronik seperti MP3 Player, LCD TV, Portable Media Player, DVD, $e$ Book, dan Disc Player. Pada tahun 2008 OPPO mulai menggarap pasar smartphone dengan menciptakan produk OPPO smartphone. Pada bulan April 2013 OPPO untuk pertama kalinya menginjakkan kaki di pasar Indonesia secara resmi. Sebelum produknya dipasarkan ke Indonesia, OPPO terlebih dahulu melebarkan sayapnya ke beberapa negara seperti, Thailand, Vietnam, Rusia, America dan Qatar. Sejak saat itu OPPO terus melakukan promosi memperkenalkan kualitas mereknya melalui iklan Media Cetak, TV, Internet, dan lain-lain. Pertumbuhan pengguna smartphone yang sangat tinggi $\mathrm{di}$ Indonesia membuat para perusahaan yang mengeluarkan produk smartphone harus berusaha menjadi yang terbaik antara perusahaan smartphone lainnya. Cara yang dapat dilakukan perusahaan dalam melakukan persaingan antara lain menentukan strategi promosi yang tepat, mencari keunggulan kompetitif yang dimiliki oleh produknya, dan membuat sebuah nama merek menjadi baik. Hal ini penting dalam sebuah perusahaan untuk 
memudahkan konsumen mengenali produk tersebut. Banyaknya perusahaan pesaing yang produknya memiliki keunggulan kompetitif membuat ekuitas merek smartphone OPPO sendiri pun dapat menurun di dalam benak konsumen. Dalam sebuah perusahaan asosiasi merek dapat membantu proses konsumen dalam mengingat informasi, membantu konsumen mengambil keputusan pembelian, dan membuat konsumen berfikir positif terhadap sebuah merek (Aaker, 1991). Masih banyaknya konsumen yang mengasosiasikan smartphone dengan merek selain OPPO menunjukan asosiasi merek yang dimiliki oleh OPPO di dalam benak konsumen tergeser oleh merek lain. Kesetiaan konsumen terhadap sebuahmerek akan membuat sulit bagi pesaing untuk memasuki pasar (Keller, 1993). Kesetiaan yang dimiliki konsumen terhadap sebuah merek akan meningkatkan pembelian yang berkelanjutan. Adanya pengguna smartphone OPPO yang tidak loyal karena pesaing smartphone lainnya sering menawarkan kelebihan atau kecanggihan dari produk smartphone tersebut. Hal ini dapat membuat konsumen smartphone OPPO beralih ke merek lain. Kesadaran merek dapat membantu konsumen mengurangi waktu dan upaya selama mengambil keputusan dalam pembelian (Stochi and Fuller, 2017). Meningkatnya kesadaran sebuah merek dalam benak konsumen juga dapat meningkatkan ekuitas sebuah merek. Produk smartphone OPPO berfokus pada kamera depan dengan kualitas foto selfie yang baik, dimana konsumen sudah mulai mengetahui bahwa produk smartphone OPPO memiliki kamera depan yang berkualitas baik. Citra merek yang baik akan memberikan benefit bagi perusahaan dan memberi pengaruh positif terhadap perilaku konsumen seperti kesetiaan terhadap sebuah merek dan memberikan ulasan yang baik untuk merek tersebut (Lee, Lee, \& Wu, 2009). Citra merek smartphone OPPO dengan kualitas yang baik dan harga yang terjangkau memberikan nilai yang positif di mata konsumen. Dalam waktu enam tahun sejak OPPO bergabung di dalam pangsa pasar smartphone di Indonesia smartphone OPPO sudah dapat menduduki peringkat kedua pada Kuartal-II 2019. Menurut (Ohanian, 1990) kredibilitas selebriti endorser adalah sejauh mana sumber dipandang memiliki keahlian yang relevan dengan topik komunikasi dan dapat dipercaya untuk memberikan pendapat obyektif tentang subjek. SmartphoneOPPO sudah memiliki kredibilitas selebriti endorse yang baik. Diantara lain selebriti endorse dari smartphone OPPO ada artis dan penyanyi baik dari Indonesia maupun diluar Indonesia. Menurut (Erdem \& Swait, 2014) kredibilitas merek sebagai 
kepercayaan terhadap informasi produk yang terkandung dalam sebuah merek, yang diperlukan konsumen untuk memahami bahwa merek memiliki kemampuan (yaitu,

\section{TELAAH LITERATUR}

Membangun brand equity sebuah merek merupakan hal yang penting dilakukan karena apabila brand equity suatu merek sudah terbangun dengan baik, maka akan memberikan efek positif pada merek tersebut. Menurut (Aaker, 2001), ekuitas merek dibagi menjadi lima kategori yaitu brand loyalty, brand awareness, perceived quality, brand associations, dan other proprietary brand assets. Penelitian ini menggunakan konsep "The Aaker Model" yang dikemukakan oleh Aaker. Konsep ini membahas tentang ekuitas merek dipengaruhi oleh brand loyalty, brand awareness, perceived quality, brand associations, dan other proprietary brand assets Menurut (Keller, 2003) citra merek yang merupakan elemendari ekuitas merek yang teridentifikasi dalam psikologikal dan dalam suatu model perilaku pengguna. Citra merek diperlukan dalam membangun sebuah ekuitas merek. Menurut Malik, Naeem, dan Munawar (2012) citra merek merupakan sebuah komponen dari ekuitas merek. Selain itu citra merek juga penting dalam meningkatkan sebuah ekuitas merek. (Keller, 2013) mengatakan menciptakan citra merek yang positif membutuhkan program pemasaran yang keahlian) dan kemauan (yaitu, kepercayaan) untuk terus- menerus memberikan apa yang telah dijanjikan.

saling mengaitkan dan kuat. Citra merek yang baik juga dapat didukung dengan asosiasi merek yang kuat juga. Menurut (Keller, 2003) asosiasi merek juga mengarah pada loyalitas merek. Asosiasi merek yang tinggi di dalam benak konsumen juga dapat membuat konsumen menjadi loyal terhadap suatu merek. (Yoo, Donthu, \& Lee, 2000) menyatakan asosiasi merek merupakan aspek yang penting untuk sebuah ekuitas merek. Menurut (Yoo, Donthu, \& Lee, 2000) loyalitas merek membuat konsumen membeli merek secara rutin dan menolak beralih ke merek lain. Ketika konsumen sudah setia pada merek maka ekuitas merek suatu merek pun akan meningkat. (Aaker, 2001) mengatakan teori tingkatan loyalitas merek dibagi menjadi lima kelompok dari yang terendah sampai yang tertinggi. Lima tingkatan loyalitas merek terdiri dari: Switcher Dimana konsumen pada tingkat ini tidak loyal dan tidak tertarik dengan merek tersebut. Habitual buyer Konsumen merasa puas dengan produk yang dibelinya dan tidak merasa kecewa dengan produk tersebut. Satisfied buyer Pada tingkat ini konsumen sudah puas dengan produk yang digunakannya. Dimana konsumen 
merasakan adanya suatu pengorbanan apabila berganti ke merek lain seperti waktu dan uang. Likes the brand Konsumen pada tingkat ini merupakan konsumen yang sudah sungguh-sungguh menyukai merek tersebut. Committed buyer Konsumen di tahap ini merupakan pelanggan yang sudah setia. Konsumen memiliki suatu kebanggaan dengan memakai produk tersebut. Menurut (Keller, 2013) ekuitas merek berbasis pelanggan terjadi ketika konsumen memiliki tingkat kesadaran dan keakraban yang tinggi terhadap merek tersebut. Kesadaran merek yang kuat dapat membantu menentfukan keputusan pembelian pada konsumen yang masih ragu dalam melakukan pembelian pada produk tertentu. (Keller, 2013) mengatakan kesadaran merek memiliki dua dimensi: "Brand recognition is consumers' ability to confirm prior exposure to the brand when given the brand as a cue. Brand recall is consumers' ability to retrieve the brand from memory when given the product category, the needs fulfilled by the category, or a purchase or usage situation as a cue." Penelitian (Sasmita \& Suki, 2016) memperlihatkan bahwa hubungan antara asosiasi merek dan ekuitas merek adalah positif dan signifikan. Semakin tinggi tingkat asosiasi merek dalam sebuah produk, maka konsumen semakin mengingat dan setia terhadap produk tersebut. Menurut (Shabbir, Khan, \& Khan, 2017), mengatakan bahwa asosiasi merek dengan ekuitas merek memiliki hubungan yang kuat satu sama lain karena asosiasi merek adalah komponen yang membantu merek untuk tetap berada di dalam pikiran konsumen. (Yoo, Donthu, \& Lee, 2000) menyatakan hubungan dimensi ekuitas merek dengan ekuitas merek berpengaruh positif khususnya antara asosiasi merek dengan ekuitas merek yang berpengaruh positif signifikan. (Sasmita \& Suki, 2016) memperlihatkan bahwa brand loyalty dan brand equity memiliki hubungan yang kuat satu sama lain karena brand associations adalah komponen yang membantu merek untuk tetap berada di dalam pikiran konsumen. (Yoo, Donthu, \& Lee, 2000) menyatakan hubungan dimensi ekuitas merek dengan ekuitas merek berpengaruh positif khusunya antara kesetiaan dengan ekuitas merek yang berpengaruh positif signifikan. Penelitian (Shabbir, Khan, \& Khan, 2017) memperlihatkan bahwa loyalitas merek memiliki dampak positif dansignifikan terhadap ekuitas merek, oleh karena itu pengiklan telekomunikasi di kota Mirpur Azad Kashmir harus memperrtimbangkan karakteristik kepribadian merek mereka dari sudut pandang konsumen dan untuk mengembangkan citra merek sesuai dengan konsep diri ideal konsumen. Penelitian (Sasmita \& Suki, 2016) memperlihatkan 
bahwa kesadaran merek berpengaruh signifikan terhadap ekuitas merek diantara konsumen muda di Malaysia dalam membeli suatu produk tergantung pada kesadaran mereka tentang produk tersebut. (Kim, Kim, \& Kim, 2008) dalam penelitiannya memperlihatkan kesadaran merek memiliki pengaruh positif terhadap ekuitas merek. Dalam penelitian (Shabbir, Khan, \& Khan, 2017) disebutkan bahwa kesadaran merek berpengaruh terhadap ekuitas merek, memiliki efek pada persepsi dan sikap konsumen terhadap sebuah merek. Penelitian (Sasmita \& Suki, 2016) menunjukan bahwa citra merek berpengaruh positif terhadap ekuitas merek pada konsumen muda di Malaysia. Fairlocht, Capella, \& Alford (2001) mengatakan citra merek yang bersifat positif dapat menambahkan nilai dari sebuah ekuitas merek. Menurut (Lee, Lee, \& Wu, 2009)tidak hanya citra merek, tetapi dua variasi dari citra merek juga memiliki hubungan dengan ekuitas merek oleh karena itu banyak perusahaan dari negara berkembang berupaya untuk mengakuisisi perusahaan dari negara maju. Kerangka pemikiran dalam penelitian ini, dapat digambarkan sebagai sebagai berikut:

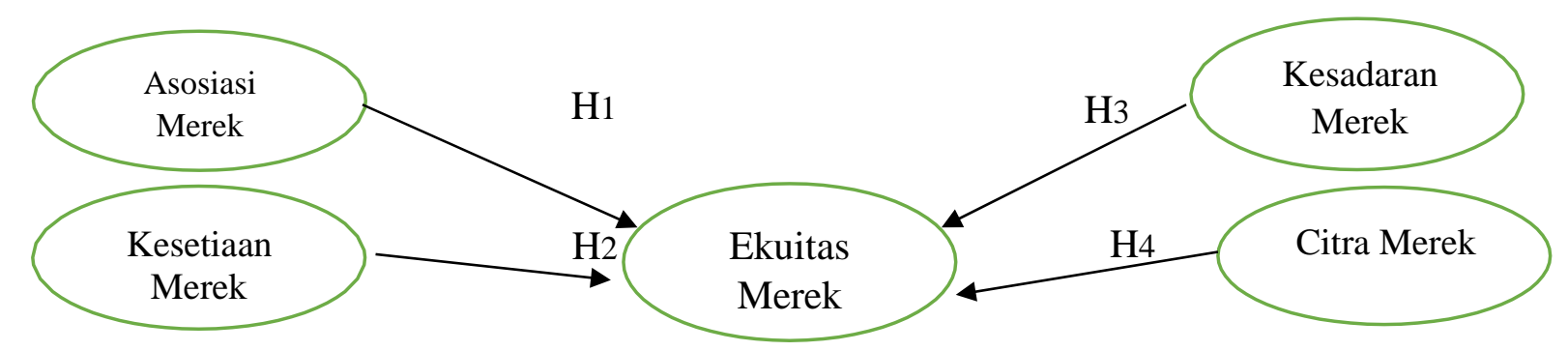

Gambar 1. Model Penelitian

\section{METODOLOGI PENELITIAN}

Desain penelitian yang digunakan dalam penelitian ini adalah desain deskriptif yang bertujuan untuk mendapatkan gambaran dari responden konsumen smartphone OPPO di Karawaci Tangerang. Variabel eksogen dalam penelitain ini adalah asosiasi merek, kesetiaan merek, kesadaran merek, citra merek dan ekuitas merek, sedangkan variable endogen adalah ekuitas merek. Penelitian ini dilakukan untuk mengetahui apakah asosiasi merek, kesetiaan merek, kesadaran merek, dan citra merek berpengaruh positif terhadap ekuitas merek handphone OPPO. Responden pada penelitian ini adalah mahasiswa/i di lingkungan Universitas Pelita Harapan Karawachi Tangerang pengguna smartphone OPPO. Menurut (Sekaran \& Bougie, 2016), ukuran sampel lebih dari 30 responden dan kurang dari 500 responden adalah tepat untuk melakukan penelitian, dan ukuran sampel sebaiknya 10 kali lebih 
besar dari jumlah dalam penelitian termasuk analisis regresi linear berganda. Jumlah yang digunakan peneliti adalah lima. Dengan demikian jumlah sampel 150 responden yang diteliti oleh peneliti telah memenuhi syarat yang ditentukan. (Sekaran \& Bougie, 2016) menyatakan bahwa analisis data merupakan sebuah tahap lanjutan yang dilakukan untuk melakukan pengujian hipotesis penelitian yang dihasilkan telah didukung. Analisis data dalam penelitian ini dilakukan untuk mengetahui pengaruh

\section{HASIL DAN PEMBAHASAN}

Pada analisis data, tahap pertama yang dilakukan adalah pengujian validitas. antara eksogen yaitu asosiasi merek, loyalitas merek, kesadaran merek dan citra merek terhadap endogen yaitu ekuitas merek. Dalam penelitian ini analisis data yang digunakan oleh peneliti adalah SEM (Structural Equation Modeling), dengan menggunakan alat ukur PLS. Teknik analisis data yang digunakan dalam menguji penelitian ini adalah Koefisien Determinasi $\left(\mathrm{R}^{2}\right)$, Predictive Relevance $\left(\mathrm{Q}^{2}\right)$, uji Path Coefficients, effect size $\left(\mathrm{F}^{2}\right)$,uji Goodness of Fit (GoF), dan pengujian hipotesis.

Validitas dibagi menjadi 2 yaitu validitas konvergen dan validitas diskriminan.

Tabel 1 Hasil Nilai Loading Factor

\begin{tabular}{|c|c|c|c|c|c|}
\hline & $\begin{array}{c}\text { Brand } \\
\text { Associations }\end{array}$ & $\begin{array}{c}\text { Brand } \\
\text { Awareness }\end{array}$ & $\begin{array}{l}\text { Brand } \\
\text { Equity }\end{array}$ & $\begin{array}{l}\text { Brand } \\
\text { Image }\end{array}$ & $\begin{array}{l}\text { Brand } \\
\text { Loyalty }\end{array}$ \\
\hline BA1 & 0.843 & & & & \\
\hline BA2 & 0.798 & & & & \\
\hline BA3 & 0.893 & & & & \\
\hline BA4 & 0.881 & & & & \\
\hline$\overline{\text { BA5 }}$ & 0.846 & & & & \\
\hline BAW1 & & 0.849 & & & \\
\hline BAW2 & & 0.691 & & & \\
\hline BAW3 & & 0.895 & & & \\
\hline BAW4 & & 0.873 & & & \\
\hline BE1 & & & 0,893 & & \\
\hline BE2 & & & 0.864 & & \\
\hline BE3 & & & 0.793 & & \\
\hline BE4 & & & 0.802 & & \\
\hline BI1 & & & & 0.899 & \\
\hline BI2 & & & & 0.910 & \\
\hline BI3 & & & & 0.910 & \\
\hline BI4 & & & & 0.917 & \\
\hline BL2 & & & & & 0.908 \\
\hline BL3 & & & & & 0.943 \\
\hline BL4 & & & & & 0.951 \\
\hline BL5 & & & & & 0.943 \\
\hline
\end{tabular}

Pada tabel 1 dapat dilihat bahwa nilai loading factor setiap telah mencapai rule of thumb yang telah diterapkan oleh Ghozali dan Latan (2015) yaitu > 0.60.

Tabel 2 Nilai Average Variance Extracted (AVE) 


\begin{tabular}{|l|c|c|c|}
\hline & $\begin{array}{c}\text { Average Variance } \\
\text { Extracted(AVE) }\end{array}$ & Nilai Minimum & Keterangan \\
\hline Asosiasi Merek & 0,728 & 0,5 & Valid \\
\hline Kesadaran Merek & 0,769 & 0,5 & Valid \\
\hline Ekuitas Merek & 0,682 & 0,5 & Valid \\
\hline Citra Merek & 0,826 & 0,5 & Valid \\
\hline Loyalitas Merek & 0,877 & 0,5 & Valid \\
\hline
\end{tabular}

Pada tabel 2 dapat dilihat nilai Average

Variance Extracted (AVE) setiap telah sesuai dengan rule of thumb yang diterapkan oleh Ghozali dan Latan (2015) yaitu $>0.50$. Dan juga dapat dilihat bahwa nilai validitas konvergen telah tercapai.

Tabel 3 Tabel Fornell-Lacker Criterion

\begin{tabular}{|l|l|l|l|l|l|}
\hline & $\begin{array}{l}\text { Asisoasi } \\
\text { Merek }\end{array}$ & Citra Merek & $\begin{array}{l}\text { Ekuitas } \\
\text { Merek }\end{array}$ & $\begin{array}{l}\text { Kesadaran } \\
\text { Merek }\end{array}$ & $\begin{array}{l}\text { Kesetiaan } \\
\text { Merek }\end{array}$ \\
\hline $\begin{array}{l}\text { Asisoasi } \\
\text { Merek }\end{array}$ & $\mathbf{0 , 8 5 3}$ & & & & \\
\hline Citra Merek & 0,691 & $\mathbf{0 , 8 7 7}$ & & & \\
\hline Ekuitas Merek & 0,425 & 0,399 & $\mathbf{0 , 8 2 6}$ & & \\
\hline $\begin{array}{l}\text { Kesadaran } \\
\text { Merek }\end{array}$ & 0,555 & 0,663 &, 0389 & $\mathbf{0 , 9 0 9}$ & \\
\hline $\begin{array}{l}\text { Kesetiaan } \\
\text { Merek }\end{array}$ & 0,600 &, 0601 &, 0393 & 0,710 & $\mathbf{0 , 9 6 9}$ \\
\hline
\end{tabular}

Tabel 3 menunjukan nilai uji FornellLacker Criterion. Tahap berikutnya adalah pengujian reliabilitas.
Pengujian reliabilitas dilakukan dengan menggunakan 2 uji yaitu, crobanch's alpha dan composite reliability.

Tabel 4 Tabel nilai Cronbach's Alpha dan Composite Reliability

\begin{tabular}{|c|c|c|c|}
\hline & Cronbach's Alpha & $\begin{array}{c}\text { Composite } \\
\text { Reliability }\end{array}$ & \\
\hline Asosiasi Merek & 0.906 & 0.930 & Reliable \\
\hline Citra Merek & 0.300 & 0.960 & Reliable \\
\hline Ekuitas Merek & 0.846 & 0.895 & Reliable \\
\hline Kesadaran Merek & 0.931 & 0.950 & Reliable \\
\hline Kesetiaan Merek & 0.953 & 0.966 & Reliable \\
\hline
\end{tabular}

Pada tabel 4 dapat dilihat bahwa nilai crobanch's alpha dan composite reliability telah mencapai dari parameter yang telah ditetapkan yaitu $>0.60$.
Dengan begitu bisa dikatakan bahwa penelitian ini reliable. Hasil dari pengujian $R$ Square disajikan dalam Tabel 5. 
Tabel 5 Nilai Koefisien Determinasi $\mathbf{R}^{2}$

\begin{tabular}{|c|c|}
\hline & R Square \\
\hline Ekuitas Merek & 0,225 \\
\hline
\end{tabular}

Pada Tabel diketahui bahwa nilai $R$ square adalah sebesar 0,225. Artinya sebesar 22,5\% variasi dari ekuitas merek dapat dijelaskan oleh asosiasi merek, kesadaran merek, citra merek dankesetiaan merek. Sisanya sebesar (100\% - 22,5\%) 77,5\% dijelaskan oleh - lain di luar penelitian ini. Mengacu pada Hanseler et al. (2009), maka nilai $R$ square dalam penelitian ini tergolong substansial. Perhitungan path coefficients dilakukan untuk mengetahui bagaimana hubungan atau keterkaitan antar - yang terdapat pada penelitian ini antara satu dengan yang lainnya. Hasil perhitungan path coefficients dan bootstrapping akan disajikan pada Gambar 4.

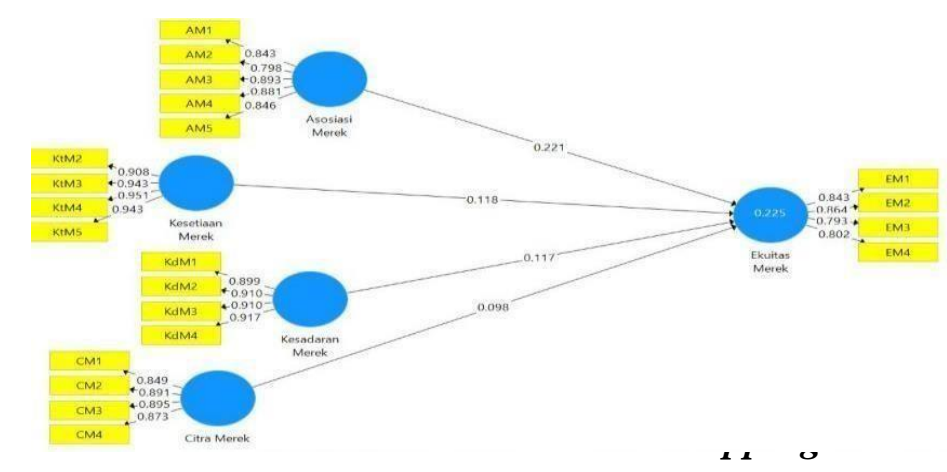

Berdasarkan gambar hasil dari gambar tersebut dapat diringkas seperti bootstrapping di atas maka hasil dari Tabel 6.

Tabel 6 Hasil Bootstrapping

\begin{tabular}{|l|c|c|c|}
\hline & $\begin{array}{c}\text { Path } \\
\text { coefficients }\end{array}$ & t-statistics & p-values \\
\hline $\begin{array}{l}\text { Asosiasi Merek -> Ekuitas } \\
\text { Merek }\end{array}$ & 0,221 & 2,082 & 0,028 \\
\hline $\begin{array}{l}\text { Kesadaran Merek -> Ekuitas } \\
\text { Merek }\end{array}$ & 0,117 & 0,848 & 0,397 \\
\hline Citra Merek -> Ekuitas Merek & 0,098 & 1,104 & 0,270 \\
\hline $\begin{array}{l}\text { Kesetiaan Merek -> Ekuitas } \\
\text { Merek }\end{array}$ & 0,118 & 1,021 & 0,308 \\
\hline
\end{tabular}

Berdasarkan hasil bootstrapping yang disajikan pada Tabel 6, maka maka dalam penelitian ini dapat dibuat persamaan sebagai berikut: $\mathrm{EK}=0,221 \mathrm{AM}+$ $0,117 \mathrm{KM}+0,098 \mathrm{CM}+0,118 \mathrm{LM}$ Nilai path coefficients pada Tabel 6 menunjukkan bahwa nilai prediksi asosiasi merek terhadap ekuitas merek memiliki pengaruh yang positif dengan nilai path coefficients sebesar 0,221. Kemudian untuk 
nilai prediksi kesadaran merek terhadap ekuitas merek memiliki nilai path coefficients yang berpengaruh yang positif sebesar 0,117 , untuk nilai prediksi citra merekterhadap ekuitas merek memiliki nilai path coefficients yang juga berpengaruh positif sebesar 0,098, dan yang terakhir untuk nilai prediksi kesetiaan merek terhadap ekuitas merek memiliki pengaruh yang positif dengan nilai path coefficients sebesar 0,118. Berdasarkan hasil boothstrapping pada tabel 6, dapat dijelaskan bahwa citra memiliki nilai path coefficients yang paling besar yaitu sebesar 0,221 dan berarah positif terhadap ekuitas merek dibandingkan pada tiga lainnya. Kriteria pada pengujian untuk mengetahui hipotesis yang terdapat pada penelitian ini tidak ditolak atau ditolak adalah dengan memperhatikan nilai t-statistics dari perhitungan bootstrapping yang telah terbentuk sebelumnya. Hasil dari pengujian hipotesis ini secara ringkas akan disajikan pada Tabel 7.

Tabel 7. Rekapitulasi Hasil Pengujian Hipotesis

\begin{tabular}{|l|l|c|}
\hline Hipotesis & \multicolumn{1}{|c|}{ Pernyataan Hipotesis } & Hasil \\
\hline H1 & $\begin{array}{l}\text { Asosiasi merek memiliki pengaruh positif } \\
\text { terhadap ekuitas merek. }\end{array}$ & $\begin{array}{r}\text { Tidak } \\
\text { Ditolak }\end{array}$ \\
\hline H2 & $\begin{array}{l}\text { Kesetiaan merek memiliki pengaruh positif } \\
\text { terhadap ekuitas merek. }\end{array}$ & Ditolak \\
\hline H3 & $\begin{array}{l}\text { Kesadaran merek memiliki pengaruh positif } \\
\text { terhadap ekuitas merek. }\end{array}$ & Ditolak \\
\hline H4 & $\begin{array}{l}\text { Citra merek memiliki pengaruh positif } \\
\text { terhadap ekuitas merek. }\end{array}$ & Ditolak \\
\hline
\end{tabular}

H1: Asosiasi merek memiliki pengaruh yang signifikan terhadap ekuitas merek. Berdasarkan hasil pada Tabel 6, asosiasi merek terbukti dapat memprediksi secara positif dan signifikan terhadap ekuitas merek pengguna smartphone OPPO di Karawaci Tangerang. Hal ini telah dibuktikan dengan nilai t-statistik sebesar 2,082 dan p-values sebesar 0,028. Sehingga dapat disimpulkan bahwa H1 tidak ditolak karena nilai t-statistik di atas 1,96 dan p-values di bawah 0,05.

H2: Kesetiaan merek tidak memiliki pengaruh yang signifikan terhadap ekuitas merek Berdasarkan hasil pada Tabel 6, kesetiaan merek terbukti dapat memprediksi secara positif dan signifikan terhadap ekuitas merek pengguna smartphone OPPO di Karawachi Tangerang. Hal ini telah dibuktikan dengan 
nilai t-statistik sebesar 1,021 dan $p$-values sebesar 0,308. Sehingga dapat disimpulkanbahwa $\mathrm{H} 2$ ditolak karena nilai t-statistik di bawah 1,96 dan p-values di atas 0,05 .

H3: Kesadaran merek memiliki pengaruh yang tidak signifikan terhadap ekuitas merek. Berdasarkan hasil pada Tabel 6, kesadaran merekterbukti dapat memprediksi secara positif dan signifikan terhadap ekuitas merek pengguna smartphone OPPO di Karawachi Tangerang. Hal ini telah dibuktikan dengan nilai t- statistik sebesar 1,104 dan p-values

\section{SIMPULAN}

Di dalam uji inner model hasil uji koefisien determinasi dalam penelitian ini memiliki pengaruh yang subtansial yaitu ekuitas merek dapat dijelaskan oleh asosiasi merek, kesadaran merek, citra merek, dan kesetiaan merek memiliki pengaruh yang besar terhadap model struktrual. Uji path coefficient nilai prediksi untuk asosiasi merek, kesetiaan merek, kesadaran merek, dan citra merek memiliki arah yang positif juga terhadap ekuitas merek terhadap ekuitas merek memiliki arah yang positif. Hasil uji hipotesis pertama adalah menunjukan bahwa asosiasi merek terbuktiberpengaruh signifikan terhadap ekuitas merek pada pengguna smartphone OPPO di Karawaci Tangerang. Semakin tinggi hasil dari asosiasi merek maka nilai sebesar 0,270. Sehingga dapat disimpulkan bahwa $\mathrm{H} 3$ ditolak karena nilai t-statistik di bawah 1,96 dan p-values di atas 0,05.

H4: Citra merek memiliki pengaruh yang tidak signifikan terhadap ekuitas merek. Berdasarkan hasil pada Tabel 6, citra merek terbukti dapat memprediksi secara positif dan signifikan terhadap ekuitas merek pengguna smartphone OPPO di Karawaci Tangerang. Hal initelah dibuktikan dengan nilai t-statistik sebesar 0,848 dan $p$-values sebesar 0,397. Sehingga dapat disimpulkan bahwa $\mathrm{H} 4$ ditolak karena nilai t-statistik di bawah 1,96 dan p-values di atas 0,05.

dari ekuitas merek akan semakin tinggi atau baik. Hasil penelitian ini sejalan dengan penelitian (Sasmita \& Suki, 2016) dan penelitian dari (Yoo, Donthu, \& Lee, 2000). Hasil uji hipotesis kedua adalah menunjukan bahwa kesetiaan merek tidak terbukti berpengaruh signifikan terhadap ekuitas merek pada pengguna smartphone OPPO di Karawaci Tangerang. Semakin tinggi kesetiaan merek maka nilai ekuitas merek akan semakin baik juga. Hasil penelitian ini tidak sejalan dengan penelitian (Yoo, Donthu, \& Lee, 2000) di mana kesetiaan merek berpengaruh positif signifikan terhadap ekuitas merek. Hasil penelitian ini bertolak belakang dengan penelitian (Shabbir, Khan, \& Khan, 2017) di mana penelitian ini dilakukan di Pakistan 
sebanyak 200 responden yang memiliki hasil bahwa kesetian merek berpengaruh positif signifikan terhadap ekuitas merek. Hasil penelitian ini juga tidak sejalan dengan penelitian (Sasmita \& Suki, 2016) yang menggunakan respoden yang berusia masih muda yang tinggal di Malaysia yang memiliki hasil bahwa kesetiaan merek berpengaruh signifikan terhadap ekuitas merek. Ketiga penelitian tersebut menyatakan kesetiaan merek berpengaruh positif signifikan terhadap ekuitas merek. Hasil uji hipotesis ketiga adalah menunjukan bahwa kesadaran merek tidak terbukti berpengaruh signifikan terhadap ekuitas merek pada pengguna smartphone OPPO di Karawaci Tangerang. Semakin baik kesadaran merek di benak konsumen maka dapat membuat nilai ekuitas suatu merek akan baik. Hasil penelitian ini tidak sejalan dengan penelitian (Kim, Kim, \& Kim, 2008) dan penelitian (Sasmita \& Suki, 2016) di mana kesadaran merek berpengaruh positif signifikan terhadap ekuitas merek. Selain itu hasil penelitian ini juga tidak didukung oleh penelitian habbir et al (2017) di mana hasil dari tiga penelitian tersebut menyatakan variable kesetiaan merek berpengaruh positif signifikan terhadap variabel ekuitas merek. Hasil uji hipotesis keempat adalah menunjukan bahwa variabel citra merek tidak terbukti berpengaruh signifikan terhadap ekuitas merek pada pengguna smartphone OPPO di Karawaci Tangerang. Semakin tinggi citra suatu merek maka akan semakin tinggi juga nilai ekuitas suatu merek. Hasil penelitian ini tidak sejalan denganhasil penelitian Fairlocht, Capella, \& Alford (2001) di mana citra merek berpengaruh positif signifikan terhadap ekuitas merek. Hasil penelitian ini tidak didukung juga oleh hasil penelitian (Lee, Lee, \& Wu, 2009) di mana citra merek berpengaruh positif signifikan terhadap ekuitas merek. Hasil penelitian ini juga tidak sejalan dengan hasil penelitian (Sasmita \& Suki, 2016) di mana citra merek berpengaruh positif signifikan terhadap ekuitas merek. Dalam penelitian ini hanya asosiasi merek yang memiliki berpengaruh positif signifikan terhadap ekuitas merek, sedangkan ketiga variabel lain kesetiaan merek, kesadaran merek, dan citra merek tidak memiliki pengaruh signifikan kepada para pengguna merek smartphone OPPO di Karawaci Tangerang. Hal ini terjadi karena asosiasi merk OPPO sebagai sebuah smartphone cukup kuat di kalangan anak muda di Karawaci, Tangerang sehingga dapat membangun ekuitas merek. OPPO memang mudah dikenali karena maraknya iklan smartphone tersebut di berbagai media seperti televisi dan media sosial, serta penggunaan perangkat promosi yang menyita perhatian seperti badut dan seragam untuk sales promotion di berbagai gerai penjualan smartphone khususnya di 
wilayah Karawaci.

\section{DAFTAR PUSTAKA}

Aaker, \& David, A. L. (2009). Brand Equity and Adversiting: Adversiting Role In Branding Strong Brand. Hillsdale: Lawrence Erlbaum Associates, inc.

Erdem, T., \& Swait, J. (2014). Brand credibility, brand consideration and choice. Journal of Consumer Research Vol.31 No.1, 191 - 9.

Keller, K. L. (2003). Conceptualizing, Measuring, and Managing Customer-Based Brand Equity. Journal of Marketing, 57(1), 1 - 22.

Keller, K. L. (2013). Strategic Brand Management . Boston: Person.

Kim, K. H., Kim, K. S., \& Kim, D. Y. (2008). Brand equity in hospital marketing 5 ". Journal of Business Research, 61, 75-82.

Lee, H. M., Lee, C., \& Wu, C. (2009). Brand image strategy affects brand equity after M\&A”. Europian journal of marketing, 45(7/8), 10911111.

Ohanian, R. (1990). "Construction and validation of a scale to measure celebrity endorsers' perceived expertise, trustworthiness and attractiveness",. Journal of Advertising, Vol. 19 No. 3, 39-52.

Roy. (2019, Agustus 30). Maaf Oppo \&
Xiaomi, Samsung Masih Rajai Pasar Ponsel RI. Retrieved from CNBC Indonesia: https://www.cnbcindonesia.com/te ch/20190830140742-3795971/maaf-oppo-xiaomi samsungmasih-rajai-pasar-ponsel-ri

Sasmita, J., \& Suki, N. M. (2016). Young consumers' insights on brand equity". International Journal of Retail \& Distribution Management, 43(3), 276-292.

Sekaran, U., \& Bougie, R. (2016). Research Methods for Business, Seventh Edition. United Kingdom: John Wiley \& Son Ltd.

Shabbir, M. Q., Khan, A. A., \& Khan, S. R. (2017). "Brand loyalty brand image and brand equity : the mediating role of brand awareness". International Journal of Innovation and Applied Studies, 19(2), 416423.

Tim Media Websindo. (2019, Maret 7). Indonesia Digital 2019. Retrieved from Websindo: https://websindo.com/indonesiadigital2019-tinjauan-umum/ 
Jurnal Bina Manajemen, September 2021 Vol. 10 No.1 hal 206 - 219

Yoo, B., Donthu, N., \& Lee, S. (2000). An

Journal of the Academy of examination of selected marketing Marketing Science,28(2), 195-211. mix elements and brand equity. 